\title{
Apresentação:
}

\section{Nação e narrativa pós-colonial, em Angola e Moçambique}

O Centro de Estudos para o Desenvolvimento de África (CeSa) do ISEG (Universidade Técnica de Lisboa) tem estado a desenvolver um projecto de investigação, apoiado pela FCT, e coordenado por Ana Mafalda Leite, intitulado Nação e Narrativa Pós-Colonial, com a participação do Centre of Postcolonial Studies da Universitá degli Studi di Napoli l'Orientale, o Research Network on Postcolonial Studies da University of Manchester e o Centro de Estudos de Literaturas e Culturas dos Países de Língua Portuguesa da Universidade de São Paulo, representados na pesquisa pelos prestigiados investigadores Iain Chambers, Hilary Owen e Rita Chaves. Integram também o projecto, a socióloga Sheila Khan, as professoras Livia Apa e Jessica Falconi da Universidade de Nápoles, e Kamila Krakowska, doutoranda da Universidade de Lisboa.

O projecto Nação e Narrativa Pós-Colonial visa responder à seguinte pergunta: que tipo de representações/imagens da nação e das identidades são propostas pelas narrativas pós-coloniais angolanas e moçambicanas? Os ensaios do dossiê deste número da Revista Via Atlântica reúnem os primeiros resultados do trabalho deste Projecto, que se centra em torno das narrativas, angolana e moçambicana, em modo comparativo e dialogante, e procura desvelar várias formas de narrar - recriando, conceptualizando - a nação, seus espaços e seus mitos, observando de que maneira o olhar do escritor é coadjuvante à criação da ideia de "nação", num trajecto entre a memória, a história, entre a espacialização territorial e a viagem, procurando a adequação de novos modos de "narrar" que integram, no seu tecido linguístico e escriptural, cruzamentos de tradições culturais, oriundas dos territórios nativos e do Ocidente.

Como Iain Chambers refere no texto de abertura "Poder, língua e a poética do pós-colonialismo" - iluminante para a reflexão teórica em torno dos trabalhos do grupo: "Habitar os espaços da cidade pós-colonial e da nação pós-colonial significa habitar uma herança dupla que é simultaneamente local e global. Se os termos são de origem claramente europeia ("literatura, arte, es- 
tética, nação") eles são ao mesmo tempo sujeitos às práticas transformativas de "desterritorialização" e "reterritorialização", conducentes a um sentido de localidade histórico e cultural. " A insistência de que o espaço pós-colonial é mais abrangente e complexo do que aquele proposto pelas fronteiras físicas dos novos estados-nação, leva Chambers a dizer que a re-escrita e reformulação do passado e do presente é também uma re-escrita das geografias da modernidade, em que os mapas se fragmentam e são ambivalentemente mais fluidos - "dentro desta ideia pós-colonial de linguagem e poética, em que as raízes de qualquer um se transformam em rotas, a localização e o enquadramento global estão ligados em novos mapas de proximidades imprevistas".

Apesar das narrativas pós-coloniais, angolana e moçambicana, não pertencerem ao sujeito europeu, elas questionam, no entanto, esse sujeito, obrigando-o à escuta, bem como questionam a linguagem crítica, a análise literária e cultural, contaminando-as e reconceptualizando-as. A questão da "colonialidade", partindo da ideia de que pensar o Sul é reconhecer que o Sul, tal como o Oriente, é um produto do Império - é tratada por Sheila Khan no seu ensaio "Ler o 'Sul' em viagem: duas epistemologias literárias do sul global em Hinyambaan e em Um estranho em Goa". Neste trabalho se observa como as deslocações e as viagens são criadoras de movimentos no sentido centro/ periferia, urbano/rural, local/global que permitem o surgimento de configurações identitárias pluralizadas, partindo da leitura analítica dos romances de João Paulo Borges Coelho e de José Eduardo Agualusa.

Hilary Owen por seu turno envereda pelo tópico da História, em "As Mulheres à beira de um império nervoso na obra de Paulina Chiziane e Ungulani Ba Ka Khosa" e analisa o papel da mulher, enquanto configuradora de diferentes imagens narrativas da nação, através da leitura de Ualalapi e de $A s$ andorinhas. Owen observa como nos textos dos dois autores moçambicanos se faz a desconstrução de mitos e genealogias de fundação da nação, através de figuras históricas conhecidas, e como a reinvenção da nação, através da escrita de Chiziane, liberta as fronteiras de género, dando lugar não apenas ao imaginário masculino, socialmente dominante.

Reescrever a História é ainda o assunto desenvolvido em "A formação da ideia de nação nos jogos de reescrita do passado colonial em A gloriosa família e O outro pé da sereia", de Kamila Krakowska. Aqui, se analisa a construção da ideia de nação através da reescrita do passado colonial nos romances de Pe- 
petela e de Mia Couto. A estratégia de reescrita está presente em vários níveis do texto com o intuito de desconstruir as narrativas oficiais do colonialismo. A análise de elementos como as figuras do narrador e do leitor, os géneros literários revisitados, revela como as obras de Pepetela e Mia Couto criam novas abordagens da história colonial que permitem reconstruir a identidade nacional angolana e moçambicana, respectivamente.

A questão da Memória e do Espaço, nomeadamente o refazer de roteiros e o deslocamento por diferentes lugares e espaços, implicando um remapeamento da nação, juntamente com a reflexão sobre momentos da história colonial, orienta o ensaio "Formas e Lugares Fantasmas da Memória Colonial e Pós-Colonial", de Ana Mafalda Leite. Discute-se também de que modo a escrita narrativa de Manuel Rui em O manequim e o piano e de João Paulo Borges Coelho em Setentrião comprometem os valores canónicos do romance ou do conto, dada a sua ambiguidade formal, dando abertura a cruzamentos de matrizes épicas e romanescas e ainda do memorialismo.

Sobre esta última questão, Rita Chaves em "Ondjaki e João Paulo: Narrativas e(m) transição" discute a produção de textos de carácter memorialístico nas duas literaturas e observa e questiona a problematização do género como o romance, que se apóia numa mesclagem com outras modalidades discursivas e outras formas narrativas, potencializando procedimentos como as referências da oralidade. Bom dia camaradas e Crónica da rua 513.2 são as obras escolhidas para discussão da construção da memória como ficção e representação de testemunhos, bem como para uma reflexão alargada sobre a especificidade das modalidades de escrita.

Com "No hay mañana sin ayer - Outras narrativas da nação em Os sobreviventes da noite, de Ungulani Ba Ka Khosa, e Actas da Maianga, de Ruy Duarte de Carvalho", Livia Apa aborda a questão da Nação entendida como corpo nacional e, nesta perspectiva, trabalha o problema das suas margens, e de como elas entram no processo de construção da identidade nacional, no contexto pós-colonial. A nação tem que enfrentar o seu recalcamento ao assumir as suas guerras de memórias, a memória da violência, num processo parecido ao que atravessa a narrativa da antiga metrópole. Neste sentido se poderá entender a memória como género textual e lugar de textualização da identidade.

Por último, a reflexão sobre a memória da violência da guerra orienta o ensaio de Jessica Falconi "A poesia da guerra como narrativa da memória na- 
cional: José Craveirinha e Ana Paula Tavares", que nos mostra como a poesia é outra forma de contar a nação. Neste texto, que encerra este dossiê, desenvolve-se uma reflexão sobre o género da poesia como construção narrativa da nação pós-colonial, e se problematiza a inclusão da produção poética no conjunto das narrativas da nação, através da produção de memória individual e cultural, impressa nos textos sobre a guerra civil, em Moçambique por José Craveirinha, e em Angola por Ana Paula Tavares. 